\title{
Foods For People With Kidney Diseases: Fundamental Guidelines \& Choice
}

\author{
*MM Rahman ${ }^{1}, \mathrm{~N}_{\text {Mahmood }}{ }^{2}, \mathrm{~A} \mathrm{Rahman}^{3}$, TT Sajani ${ }^{4}, \mathrm{~K} . \mathrm{Alo}^{5}$ \\ $1 *$ Prof. Dr. Md. Mahfuzar Rahman, Professor and Head, Dept. of Community Medicine, AKMMC \\ ${ }^{2}$ Dr. Nazneen Mahmood, Assoc. Professor and Head, Dept. of Nephrology, AKMMC \\ ${ }^{3}$ Dr. Md. Atiqur Rahman, Assoc. Professor, Dept. of Community Medicine, AKMMC \\ ${ }^{4}$ Dr. Tabassum Tahmin Sajani, Asstt. Professor, Dept. of Community Medicine, AKMMC \\ ${ }^{5}$ Dr. Kamrunnahar Alo M.Phil Part-I (Physiology course) at Sir Salimullah Medical College (SSMC), Dhaka \\ *Corresponding Author
}

Date of Submission: 26.08 .2015

Date of Acceptance: 13.10 .2015

\begin{abstract}
Chronic Kidney Disease (CKD) leads to increased cardiovascular mortality and a loss of disabilityadjusted life years. In addition lack of data / information in most low- and middle-income countries made it difficult to ascertain the true burden. Moreover, high incidence and prevalence of CKD is being driven by regional and global increase in the prevalence of Diabetes Mellitus (DM), hypertension, obesity and aging in particular. Community surveys indicate people with end-stage kidney disease are only the tip of "CKD iceberg." Therefore, preventive strategies of CKD must involve educating the population creating public awareness with early detection of CKD. The paper highlights categories of healthy foods for the people with kidney diseases for one's better choice and alternatives in choosing one's meal plan. Therefore, to deal with CKD emphasis should be given on people's awareness about fundamental guidelines and choice of available foods in order to prepare a kidney friendly diet towards better and prolong life.
\end{abstract}

Key Words: CKD, Incidence, Prevalence, Kidney Friendly Diet

\section{Introduction}

Persons more than 65 years of age constitute a substantial and growing fraction of people having the End-Stage Renal Disease (ESRD) ${ }^{1}$. Renal Data System of US (USRDS) indicates that the incidence rates of ESRD have continued to increase among those 65 and older ${ }^{2}$. Studies examining the factors affecting survival of elderly patients put on dialysis, age at start of dialysis and multiple co morbidities have been found most implicated ${ }^{3-5}$. However, a recent study showing dialysis might not offer a survival benefit in patients over 75 ages with multiple co morbidities, especially if having ischemic heart disease ${ }^{6}$. Moreover, functional dependence, impaired intellectual status, diabetes, malnutrition (low serum albumin) peripheral vascular disease and late referral for ESRD treatment are also seen as poor prognostic factors in the elderly ${ }^{7-8}$. Diet will vary based on general needs, but will be most impacted by the stage of kidney failure and of end- stage renal disease. Studies have shown that irrespective of type of dialysis received a low protein diets (hypoproteic) can help postpone dialysis ${ }^{9}$. Protein is important in diet because it helps keep the body nourished and healthy to fight off potential infections, repair tissue and for growth. A healthy diets overall the best to select trimmed cuts of meat or low fat dairy. Nuts and beans are also a good source of protein, but also contain phosphorus. Moreover, a hyperkalemia or high level of potassium in the body is associated with a significant increase in an irregular heartbeat and sudden death as well ${ }^{10}$. Therefore, preventive strategies of CKD must involve educating the population on how to prevent renal disease; risk involved in the development of CKD; public awareness on food for the people with kidney diseases, lifestyle of susceptible individuals; early detection of CKD; and creating facilities for global assistance in generation database ${ }^{11}$. 
In considering CKD it is important to maintain healthy weight with low salt intake to control blood pressure, a meal that will control DM. The basis and guidelines of the meal plan for a kidney friendly diet deserves consideration of calories, protein, carbohydrates, fat, nutrition facts and portion. However, role of dieticians in that case is vital for consultation. In a diet calorie comes from protein, carbohydrate and fat but it is to be remembered that one's need depends on individual age, sex, body size and activities and thus be adjusted as per body weight goals.

In addition, protein is needed but too much of it can be a problem. Again the amount of protein depends on body size \& activity level. It is recommended to limit protein or change their sources. One can follow the sources of lower protein foods and higher protein foods mentioned below:

Lower protein foods includes; bread, fruits, vegetables, pasta and rice

Higher protein foods includes; meat, poultry, fish, eggs

Carbohydrates are the easiest energy source in use but healthy sources include fruits and vegetables and unhealthy sources are sugar, honey, hard candies \& soft drinks. Moreover some carbohydrates are high in potassium and phosphorus that is to be considered as per the stage of CKD. A person with additional DM it is wise to take help in dealing carbohydrate in the meal plan with a dietitian in particular.

Too much fat can lead to weight gain and heart disease therefore choice of healthier fats in a meal plan is essential e.g. unsaturated fats Olive oil, Vegetable oils. It helps reducing cholesterol. If one need gaining weight it is better to eat more unsaturated fats but if losing weight is concern limit unsaturated fat? Consider examples of bad fat (Saturated) that includes; butter, lard, meats. However, removing the skin from chicken can help limit saturated fat.

Be careful with salt substitutes in reducing sodium in foods. Many salt substitutes are high in potassium which is dangerous for someone suffering with CKD.

The following nutrition facts will help deciding how much protein; carbohydrates, fat and sodium are in each serving of a food. One can pick it up that are high in nutrients that is needed and low in nutrient should limit.

Eating too much of healthy food can be a problem and thus to control one's portions / part or share eat slowly and stop eating when not hungry anymore if anyone eat too quick there is chance of eating more than need. Avoid eating while doing something like TV watching, driving as it is distracting hoe much eating. It is good to avoid eating directly from package instead taking out one serving of food and put the bag or box away.

Limit potassium, phosphorus, and fluids in consultation with physician or dietitian in particular. The following examples are the high and low potassium, and phosphorus containing foods one can choose in consultation with physician or dietitian.

Lower potassium foods includes; apple, grapes, strawberries, cauliflower, onion, lettuce, pita, white bread

Higher potassium foods includes; bananas, melons, oranges, potatoes, tomatoes, beans

Lower phosphorus foods includes; rice cereals and cream of wheat unsalted popcorn, some light colored sodas \& lemonade

Higher phosphorus foods includes; whole-grain bread, bran cereals and oatmeal, nuts and sunflower seeds, dark-colored colas

One may not need much fluid due damage in kidney and too much will be dangerous. It can lead to high blood pressure, swelling and heart failure. Extra fluid will affect lungs and will make hard to breath. Limit fluid in consultation with physician or dietitian on how much one can drink. Foods that melt like; ice, ice cream and gelatin have lot of water. It is true for many other fruits \& vegetables that must be taken in consideration to avoid extra fluid. Limit sodium to help cut down on thrust. If one still feel thirsty might try with chew gum, by rinsing mouth.

Take help of your physician or dietitian about any vitamins, supplements or over the counter medicines that one taking. Some may be harmless, but other can be dangerous for kidney more or can cause other health problems ${ }^{12}$. 


\section{Literature Review}

Kidneys filter toxins from your body and regulate body fluids and electrolytes sodium and potassium. Its failure results immediate symptoms of nausea and vomiting due to toxin in the blood. People having chronic kidney disease can be able to modify their diets to reduce stress on these vital organs although no diet is good for everyone. Dietician \& physician (nephrologists in particular) in consultation with patient can make a meal plan specific for you in addition to follow up laboratory tests. This article highlights categories of healthy foods for the people of kidney disease as an option to choose.

In BREAKFAST one egg is enough to meet the demand of protein without much of added fat. In addition white toast and a small glass of skim milk will be suitable as a kidney-preserving meal.

LUNCH may include many colored vegetables as salad with some grilled chicken to start. Low fat salad dressing is preferable. In maintain hydration between meals a large glass of water will be enough.

DINNER may add a fruit beverage that may help maintaining a well balanced diet within list of fruits restrictions. Additional one piece of $6 \mathrm{oz}$ grilled salmon, with some steamed white rice can be a better choice along with half a fresh banana for dessert.

(Source: Meal Plan for Kidney Diseases Last updated: Feb 21, 2014 by Jennifer) ${ }^{14}$

Moreover, foods that contain antioxidants can help neutralize free radicals and protect body. Many of such foods can be an excellent choice and be included in the kidney diet or people with CKD. The quantity and composition of TOP 15 health foods for people with kidney diseases are furnished below as an option or choices to make diet health and friendly as well. However, some of those may not be available in the local market in many countries.

\begin{tabular}{|c|c|c|c|c|}
\hline Sl. no & Name of foods & Quantity & Composition & Remarks \\
\hline 1 & $\begin{array}{l}\text { Red } \\
\text { peppers }\end{array}$ & Half cup serving & $\begin{array}{l}1 \mathrm{mg} \text { sodium } \\
88 \mathrm{mg} \text { potassium } \\
10 \mathrm{mg} \text { phosphorus }\end{array}$ & $\begin{array}{l}\text { Low potassium, tasty } \\
\text { vegetable, source of Vit } \\
\text { C \& A. Also an } \\
\text { appetizer }\end{array}$ \\
\hline 2 & Cabbage & Half cup serving & $\begin{array}{l}6 \mathrm{mg} \text { sodium } \\
60 \mathrm{mg} \text { potassium } \\
9 \mathrm{mg} \text { phosphorus }\end{array}$ & $\begin{array}{l}\text { High Vit K, C and fiber. } \\
\text { Good source of Vit B6 } \\
\& \text { folic acid \& in low } \\
\text { potassium \& low cost }\end{array}$ \\
\hline 3 & Cauliflower & $\begin{array}{l}\text { Half cup serving } \\
\text { boiled }\end{array}$ & $\begin{array}{l}9 \mathrm{mg} \text { sodium } \\
88 \mathrm{mg} \text { potassium } \\
20 \mathrm{mg} \text { phosphorus }\end{array}$ & $\begin{array}{l}\text { High in Vit C \& good } \\
\text { source of folate and } \\
\text { fiber }\end{array}$ \\
\hline 4 & Garlic & 1 clove & $\begin{array}{l}1 \mathrm{mg} \text { sodium } \\
12 \mathrm{mg} \text { potassium } \\
4 \mathrm{mg} \text { phosphorus }\end{array}$ & $\begin{array}{l}\text { Prevent plaque, lowers } \\
\text { cholesterol \& reduce } \\
\text { inflammation }\end{array}$ \\
\hline 5 & Onions & Half cup serving & $\begin{array}{l}3 \mathrm{mg} \text { sodium } \\
16 \mathrm{mg} \text { potassium } \\
3 \mathrm{mg} \text { phosphorus }\end{array}$ & $\begin{array}{l}\text { Powerful antioxidant } \\
\text { works to reduce heart } \\
\text { disease \& protect many } \\
\text { cancer }\end{array}$ \\
\hline 6 & Apples & $\begin{array}{l}1 \text { medium apple } \\
\text { with skin }\end{array}$ & $\begin{array}{l}0 \mathrm{mg} \text { sodium } \\
158 \mathrm{mg} \text { potassium } \\
10 \mathrm{mg} \text { phosphorus }\end{array}$ & $\begin{array}{l}\text { Reduce cholesterol, } \\
\text { prevent constipation, } \\
\text { protect heart disease \& } \\
\text { reduce risk of cancer. } \\
\text { High fiber, ant- } \\
\text { inflammatory. Apple a } \\
\text { day keep doctor away }\end{array}$ \\
\hline 7 & Blue berries & $\begin{array}{l}\text { Half cup serving } \\
\text { fresh }\end{array}$ & $\begin{array}{l}4 \mathrm{mg} \text { sodium } \\
65 \mathrm{mg} \text { potassium } \\
7 \mathrm{mg} \text { phosphorus }\end{array}$ & $\begin{array}{l}\text { High in anti-oxidant \& a } \\
\text { good source of Vit C }\end{array}$ \\
\hline 8 & Cranberries & $\begin{array}{l}\text { Half cup serving } \\
\text { dried }\end{array}$ & $\begin{array}{l}2 \mathrm{mg} \text { sodium } \\
24 \mathrm{mg} \text { potassium } \\
5 \mathrm{mg} \text { phosphorus }\end{array}$ & $\begin{array}{l}\text { Protect bladder infection } \\
\& \text { stomach ulcer. Also } \\
\text { protect cancer \& heart } \\
\text { disease }\end{array}$ \\
\hline 9 & Raspberries & Half cup serving & $\begin{array}{l}0 \mathrm{mg} \text { sodium } \\
93 \mathrm{mg} \text { potassium } \\
7 \mathrm{mg} \text { phosphorus }\end{array}$ & $\begin{array}{l}\text { Source of manganese, } \\
\text { Vit C, fiber and folate \& } \\
\text { Vit B. Inhabit cancer } \\
\text { cell growth \& tumor } \\
\text { formation }\end{array}$ \\
\hline 10 & Strawberries & $\begin{array}{l}\text { Half cup serving } \\
\text { fresh }(5 \text { medium })\end{array}$ & $\begin{array}{l}1 \mathrm{mg} \text { sodium } \\
120 \mathrm{mg} \text { potassium } \\
13 \mathrm{mg} \text { phosphorus }\end{array}$ & $\begin{array}{l}\text { Source of Vit C, } \\
\text { manganese \& fiber, } \\
\text { Protect heart, having } \\
\text { anti-cancer\& ant- } \\
\text { inflammatory }\end{array}$ \\
\hline 11 & Cherries & $\begin{array}{l}\text { Half cup serving } \\
\text { fresh }\end{array}$ & $\begin{array}{l}0 \mathrm{mg} \text { sodium } \\
160 \mathrm{mg} \text { potassium }\end{array}$ & $\begin{array}{l}\text { Reduce inflammation, } \\
\text { Anti-oxidant \& protect }\end{array}$ \\
\hline
\end{tabular}

(Source: Da vita renal dietitian, Sara Colman, RD, CSR, CDE) $)^{15}$ 
Foods For People With Kidney Diseases: Fundamental Guidelines \& Choice

\section{Conclusion}

A well balanced diet plan is important for maintaining good health in case of CKD but compliance, choice and consideration in addition to consultation with nephrologists and dietitian is important because it help prevent further damage of the kidneys. Depending on the stage of CKD it is better to limit potassium, phosphorus and fluids.

\section{Recommendations}

- It is important educating people through public awareness program how to prevent kidney disease, and the risk involved in CKDs

- Importance should be given through motivation of the population in choosing healthy foods having kidney disease and its compliance in consultation with nephrologists \& dieticians in particular

- Regular follow up evaluation \& monitoring is important for better compliance \& confidence among clients \& providers

- Cost minimization \& choice of treatment options should be rational \& well informed

- A large scale community based survey is essential to generate real scenario of kidney disease in our setting to have a data base in making future plan of action.

- Measures should be taken towards early detection $\&$ prevention of Kidney diseases through active surveillance including other Non Communicable Diseases (NCDs) like; Diabetes, Hypertension, Cancer, Obesity, and Aging in particular

\section{Conflict of Interest}

The authors have no conflict of interest to anybody

\section{References}

1. Stel VS,van de Luijtgaarden MW, Wanner C et al. The 2008 ERA-EDTA Registry Annual Report - a precis. NDT Plus. 2011;4(1):1-13.

2. Coresh J, Selvin E, Stevens LA et al. Prevalence of chronic kidney disease in the United States. JAMA. 2007;298:2038-2047.
3. Chandna SM, Schuz J, Lawrence $\mathrm{C}$ et al. Is there a rationale for rationing chronic dialysis? A hospital based cohort study of factors affecting survival and morbidity. BMJ. 1999; 318: 217-223.

4. Verdalles U, Abad S, Aragoncillo I et al. Factors predicting mortality in elderly patients on dialysis. Nephron Clin Pract. 2010;115:c28-c34

5. O'Hare AM, Choi AL, Bertenthal D et al. Age affects outcomes in chronic kidney disease. J Am Soc Nephrol. 2007;18: 2758-2765.

6. Murtagh FE, Marsh JE, Donohoe P et al. Dialysis or not? A comparative survival study of patients with chronic kidney disease stage 5. Nephrol Dial Transplant. 2007;22:1955-1962.

7. Smith C, Da Silva-Gane M, Chandna S et al. Choosing not to dialyse: evaluation of planned non dialytic management in a cohort of patients with end-stage renal failure. Nephron Clin Pract. 2003;95:c40-c46.

8. Joly D, Anglicheau D, Alberti C et al. Octogenarians reaching end-stage renal disease: cohort study of decisionmaking and clinical outcomes. J Am Soc Nephrol. 2003; 14: 1012-1021.

9. Capusa C, Garneata L, Mircescu G, Stancu, S. Effects of a Supplemented Hypoproteic Diet in Chronic Kidney Disease. Journal of Renal Nutrition, May 2007;17(3).

10. Sudden Cardiac Death in Hemodialysis Patients: An InDepth Review. American Journal of Kidney Disease. http://www.ajkd.org/article/S0272-6386(11)005956/fulltext\#sec2.4

11. Burden of Chronic Kidney Disease: An International Perspective. Available from: http:// www.ncbi.nlm.nih.gov/ pubmed/ 20439090

12. Kidney-Friendly Diet and Foods: Healthy Eating for People with Chronic Kidney Disease. Available from: http://www.kidneyfund.org/kidney-disease/kidneyfriendly-diet-ckd/

13. Control kidney disease through diet. Available from: http://timesofindia.indiatimes.com/life-style/healthfitness/health -news/Control-kidney-disease-throughdiet/articleshow/5433294.cms

14. Jennifer Hartford Meal Plan for Kidney Diseases Last Updated: Feb 21, 2014

15. Sara Colman, RD, CSR, CDE Top 15 Healthy Foods for People with Kidney Disease by DaVita ${ }^{\circledR}$ renal dietitian. 